Paulina Pokojska, Wojciech Pokojski

Laboratory of Computer Education and GIS

E-mail: wpokojski@uw.edu.pl

\title{
GEOGRAPHICAL DIMENSION OF INTERNET DOMAINS
}

\begin{abstract}
One of the two highest levels of Internet domains has its geographical dimension. It consists of the so-called country-code domains (ccTLDs) assigned to the individual countries of the world according to the standard ISO 3166. Some of these domains took over the role of worldwide functional domains and large income from their sale caused economic and social changes in the countries with attractive country-code domains.
\end{abstract}

Key words: Internet, country-code domains, functional domains

\section{INTRODUCTION}

Internet domains have their geographical dimension. According to the standard ISO 3166, countries of the world are assigned two-character country-specific domains. Even a few years ago, the Internet domain indicating the country of the registration of the Internet address, apart from the language, determined the origin of an Internet page. In recent years some country-specific domains took over the role of worldwide functional domains, and proceeds from the sale of these domains effected economic and social changes in countries with an attractive country-specific domain.

\section{ORGANISATION OF INTERNET DOMAINS}

Technical matters are regulated by the decisions of IETF (Internet Task Engineering Force) and IANA (Internet Assigned Number Authority). IANA manages a very important from the point of view of Internet users system of domain names (DNS - Domain Name System).

A domain address consists of a few elements read from right to left. The rightmost element, not ending with a dot, is called the Top Level Domain (TLD). The second element is called the Second Level Domain (SLD). Each element is a subdomain of the preceding domain (Waglowski, 2005). 
The highest level of domains is divided into two basic categories: generic domains (gTLDs - generic Top Level Domains) and country-code domains (ccTLDs - country-code Top Level Domains).

Nowadays 14 generic domains (gTLDs) are in operation:.com,.org,.mil,. gov,.int,.net,.edu,.info,.biz,.name,.pro,.museum,.coop,.aero. Assigning of these domains is performed by organisations from the United States.

Country-code domains (ccTLDs) use two-letter abbreviations that have been assigned to individual countries since 1974 according to the table ISO 3166-1 managed by the International Organization for Standardization (ISO) ${ }^{1}$. In some countries the registration and supervision of country-code domains is given to specialised institutions ${ }^{2}$. Poland received the domain "pl". Until 2005, 248 country-code domains have been assigned.

Some of the two-letter country-code domains, apart from identifying the country, have a meaning in other fields of life or in other languages. Such domains have been transformed by the market into top-level functional domains. Countries with attractive domains take advantage of this situation to gain profit and promote their own country. In some cases the assignment of the domain turned out to be manna from heaven sui generis.

Table 1.

Attractive country-code domains

\begin{tabular}{|l|l|l|}
\hline Domain & Country & Eksplanations of abbereviations \\
\hline am & Armenia & A type of radio frequency \\
\hline cc & Cocos (Keeling) Islands & terms Carbon copy and Creative Commons, \\
\hline cd & Democratic Republic of the Congo & term Compact disc \\
\hline fm & Federated States of Micronesia & A type of radio frequency \\
\hline md & Moldova & term Medical doctor \\
\hline nu & Niue & French-language pages \\
\hline sa & Saudi Arabia & In Poland type of company \\
\hline tm & Turkmenistan & term Trademark \\
\hline to & Tonga & Popular Slav word \\
\hline tv & Tuvalu & Television \\
\hline ws & (Western) Samoa & term Website \\
\hline
\end{tabular}

Source: Author's own materials, based on http://www.icann.org

\section{EXAMPLES OF ATTRACTIVE COUNTRY-CODE DOMAINS}

\section{Tuvalu (tv)}

For the small islands of Tuvalu located on the Pacific Ocean, Internet became the source of a sudden material profit. The islands are inhabited by

' ISO $3166-1$ is a part of the standard ISO 3166 , containing the principles of coding and codes for countries and territories. It was published for the first time in 1974.

${ }^{2}$ http://www.icann.org/cetlds. 
11300 people (2003). In 2000, national income per inhabitant was 1100 USD. Until 2000, the basis of the state budget consisted of agriculture, money transfers from citizens working abroad and issue of postal stamps valued by stamp collectors. Until 2000 Tuvalu could not become a member of the United Nations because of too high membership dues (Skiepko 2000). The assignment of the domain "tv" in 2000 resulted in improvement of the economic situation of the islands. From the organisational point of view, the small country wasn't able to manage this privilege. The government of Tuvalu signed an agreement with the American company DotTV for the amount of four million USD yearly (50 million USD over 12 years) for the exclusive rights to sell the domain "tv". Since April 2000 Internet addresses in this domain can be found on Internet auctions.

The increase of the state budget by about $30 \%$ allowed the country not only to join the United Nations, but also to improve the economic situation of the islands. The most expensive currently available Internet addresses www.news.tv and www.business.tv cost one million USD each.

It is worth noting that in 2002 there were 1300 Internet users registered in Tuvalu.

\section{Niue (nu)}

A similar privilege was the share of the small state of Niue, an overseas territory of New Zealand, located $2400 \mathrm{~km}$ north of New Zealand. The "nu" domain is extremely popular in French-speaking countries and in Sweden. "Nu" in French means "naked" while in Swedish, "now" (Skiepko, 2000).

Since 1997 the control over the "nu" domain has been in the hands of the American company Internet Users Society which is at the same time an Internet Service Provider on the islands - a difficult challenge because of the location of the islands. The surface area of the islands is $169 \mathrm{~km}^{2}$ and the population is 18000 . Because of their isolation and lack of perspectives for development only around $10 \%$ of the native inhabitants remained on the islands. Since 1999 the communication over the Internet stopped the isolation of the islands and made possible a free-of-charge contact of the inhabitants with their families living mostly in New Zealand and Australia. The construction of the network was financed mostly thanks to the proceeds from the sale of the "nu" domain to the companies form Sweden and Frenchspeaking countries. Nowadays, Internet access is free-of-charge for all inhabitants of the islands. Internet became so common that it supplanted the traditional telephone service.

Until January 2003, over 100000 domains "nu" had been registered (Clair $R, 2003$.

Additionally, web sites registered in the "nu" domain became a way of promoting the country.

\footnotetext{
${ }^{3}$ http://www.frazpc.pl
} 


\section{Micronesia ( $f m$ )}

The Federal States of Micronesia also takes advantage of its attractive Internet domain and earns money from its sale. One of Poland's largest radio stations has the address in the " $\mathrm{fm}$ " domain ${ }^{4}$. Web search engines show several tens of addresses of web sites of Polish radio stations registered in this domain. Also companies selling audio/video equipment have Internet addresses in the "fm" domain.

On the web site http://www.fm, apart from the possibility of creating a website in the "fm" domain, one can admire beautiful photos of the islands and find out about the tourist services offered to the public. It is interesting that the official web site of the government of the Federated States of Micronesia and the web site of the information centre of this country are not in the "fm" domain, but in other domains of the gTLD level.

\section{Congo (cd)}

The Democratic Republic of Congo also profits from having an attractive Internet domain "cd". The domain is sold by the appropriate governmental agency. This domain is recognised worldwide as the functional domain of the compact discs makers. This domain is used also by artists and music producers.

\section{Moldova ( $m d$ )}

The country-code domain of Moldova, "md", is used outside the country mostly in the healthcare industry. It is used by medical information centres, medical foundations and centres of alternative medicine.

\section{Cocos Islands (cc)}

The abbreviations "cc" is recognised in many languages and has many meanings. In the US the abbreviation "cc" means, among other things, the international organisation Creative Commons, devoted mainly to working out and promoting licenses allowing for the extension of the current scope of the copyright according to the needs of the progress of the technology development. In Poland the abbreviation "cc" has a meaning in medicine, the automotive industry, etc.

The "cc" domain is one of the least expensive country-code domains.

\section{CONCLUSIONS}

Internet is developing very fast. Data about the number of country-code Internet domains from a few years ago are nowadays of almost archival

\footnotetext{
${ }^{4}$ http://www.rmf.fm
} 
value; nonetheless they allow for tracking the attractiveness of the countrycode domains ${ }^{5}$. In 2003 the Cocos Islands were on the sixth position in this list, the Tuvalu islands on the fifteenth, while the Western Samoa, on the seventeenth. It is worth noting that in Poland, the number of the "pl" domains was 175000 in 2003 and in September 2005, already 351 000. During two and a half years the number of "pl" domains doubled.

Attractive country-code domains taking over the function similar to those of functional domains play a significant role in the case of very small and poor countries. Income from the sale of addresses constitute an important share of the national income of these countries.

\section{REFERENCES}

Cla ir R., Niue's nu. Internet User Society, White Paper 1/2003.

Ski epk o T., Tuvalu w ONZ dzięki sieci [Tuvalu in the UN thanks to the Net; in Polish]. PC World Komputer, 6 October 2000.

Waglowski P., 2005, Prawo $w$ sieci. Zarys regulacji internetu [Law in the Network. An Outline of the Regulation of the Internet; in Polish], Wyd. Helion.

English translation: Matgorzata Mikulska able.

${ }^{5}$ Newer data about the number of the individual country-code domains are not avail- 